\title{
Sarawak Digital Economy and The Organisational Sensemaking Process of CSR: A Conceptual View
}

\author{
DAYANG AIZZA MAISHA ABANG AHMAD \\ JAMILAH AHMAD \\ SURIATI SAAD \\ Universiti Sains Malaysia
}

\begin{abstract}
The Sarawak Digital Economy (SDE) is an initiative that was recently implemented by the Sarawak Government in its effort to turn Sarawak into a high-income and developed State by year 2030. Based on this vision, the Sarawak Government has addressed the critical need for an effective collaboration with the local organisations. Since the early 2000s, Corporate Social Responsibility (CSR) has become one of the innovative mechanism used by governments of various localities to work with local organisations for the interest of the community. In some regions, CSR has been widely used as a platform to cope with the social challenges such as unemployment and poverty. Based on these common practices, it is reasonable for this study to anticipate the likelihood for similar mechanism of collaboration to take place in Sarawak especially in respective to the joint effort required between the Sarawak Government with the local organisations to ensure successful implementation of SDE. This perspective in turn, puts into emphasis the potential 'trigger' effect that SDE may impose on the affected local organisations, including its CSR activities and orientation. Henceforth, the need for this study to view the development and implementation of CSR in an organisation as a sensemaking process. In this respect, this article takes the pioneering step to put present a conceptual view of the organisational CSR sensemaking process, and rationalise as to how CSR should be analysed especially in the scope of Sarawak's current economic plan and direction.
\end{abstract}

Keywords: Corporate Social Responsibility (CSR), sensemaking, Sarawak digital economy, organizational sensemaking, CSR sensemaking.

\section{INTRODUCTION}

At the size of 124,449.5 square kilometers, Sarawak makes the largest state in Malaysia with an estimated population of 2.77 million to date (Sarawak Government, 2018; Department of Statistics Malaysia, 2018). Consisting of 11 divisions and 31 districts, Sarawak is home to more than 40 sub-ethnic groups with diverse cultures, lifestyles, and languages. Apart from being distinctively known for its multicultural population and unique attractions, Sarawak's geographical landscape and strategic location have also successfully drawn continuous business interests from both local and foreign investors (Sarawak Government, 2018). Subsequent to its independence in 1963, Sarawak has experienced vast economic progress. Since the past decades, the State's immense economic growth can be detected through various measures (e.g. increased in Gross Domestic Product and total exports, improvement of monthly household income and poverty rate) (The Star Online, 2015; Department of Statistics Malaysia, 2017; Ogilvy, 2018). To ensure Sarawak's continuous progress, the Sarawak Government took a major leap by taking the State's economic development plan to 
another level. That is, by introducing the people of Sarawak to the global economic trend of Digital Economy.

The Sarawak Digital Economy (SDE) is the State's new economic focus that aims to bring the local community at par with the global economic trend of 'going digital'. The SDE initiative envisions to pave ways for the local community to capitalise and optimise the economic opportunities that the digital sphere can offer (State Service Modernisation Unit, 2017). In moving towards the vision of SDE, a strong collaborative effort is necessary between the government and local organisations. The local organisations in the scope of this article refer specifically to the Sarawak Government-Linked Companies (GLCs) due to its direct involvement in the implementation of SDE. Establishing the profile of the local organisations understudy is required in order to determine the basis and context of the proposed conceptual framework. As Sarawak's main service providers, GLCs plays a significant role on the State's economy at large. The vital functions of GLCs can also be seen through its Corporate Social Responsibility (CSR) initiatives that have consistently contributed to the State's socioeconomic progress. Particularly, by way of assessing societal concerns and investing in areas that can impact Sarawak's sustainable development through suitable CSR platforms.

GLCs in Sarawak has been highly visible in its CSR pursuits. The Sarawak Information Systems Sdn. Bhd., (SAINS) for instance, has emerged to be one of the prominent GLCs that have been rigorously involved in CSR activities (Tuah, 2017). Through its annual CSR programs like the CSR Rural ICT Guided Home-based Technopreneur (RiGHT), SAINS has tremendously contributed to the socioeconomic improvement of the underprivileged communities residing in the rural Sarawak (Davendran, 2013; Sarawak Information Systems Sdn. Bhd., 2018). This significant link between the vital role of GLCs and the emerging importance of CSR in Sarawak development raises the critical need to analyse the meaning making process of GLCs on its CSR, particularly in response to the State's new economic environment - the Sarawak Digital Economy.

Taking into consideration the preliminary stage of this research and its direction, it is imperative for the conceptualisation of CSR in this current analysis to be built upon a definitional construct that is highly relevant, widely used, and frequently reviewed and discussed (Visser, 2006; Jamal \& Mirshak, 2007; Nulawadin, 2012; Calabrese, Costa, Menichini, Rosati, \& Sanfelice, 2013; Hamid, Atan, \& Saleh, 2014; Igwe, Icha-Ituma, \& Madichie, 2018). Based on this rationale, this research defines CSR in accordance to Carroll's Four-Part CSR Pyramid (1979; 1991; 2016). Carroll's dynamic and adaptable CSR framework is believed suitable to serve as basis to structuring and delineate CSR for the scope of the intended analysis in this current study. In reference to Carroll's CSR Pyramid (1979; 1991), this study categorizes organisational CSR responsibilities into four categories (i.e. economic, legal, ethical and philanthropic). The degree of importance of each category however may differ depending on the organisations' respective CSR priorities. For the purpose of this research, each responsibility in the pyramid are interpreted as an independent yet interrelated concepts (Carroll, 2016). In other words, the four responsibilities can be interpreted as different, as well as an integrated and/or unified whole of the CSR Pyramid.

Where CSR development in Sarawak is concerned, the practical implication of SDE on GLCs certainly amplifies the need for an adaptive and context-related approach to CSR development. Without neglecting its own organisation-specific CSR goals and orientations, this approach necessitates the organisations to comply to the current expectations of its external environment (Godfrey \& Hatch, 2007; Basu \& Palazzo, 2008). Henceforth, requires 
the assigned GLCs to translate its meaning of CSR into the SDE context of which the organisations operate. In reference to Weick (1995), this 'translation' task that is required of GLCs necessitates performing an internal search process of meaning making and collectivizing the organisation-specific approach to developing CSR. This process is what this research refers to as the organisational CSR sensemaking.

As an adjunct to Public Relations (PR), CSR plays a significant function in establishing organisation's external relationships; thus, making CSR a vital peripheral activity that carries a great degree of importance not only within external affairs, but also the corporate affairs and community affairs of the organisational structure (Frankental, 2001). From the PR standpoint, understanding the meaning making process of the organisation's CSR would be a proactive measure to ensuring the CSR model or CSR effort developed and implemented by the organisation is not limited to only participating in social and economic regeneration initiatives; but also, complying to the needs of the triple-bottom line requirements (Elkington, 2013) as well as to respond effectively to any changes emerging from a new phenomenon faced by the organisation. Following Weick (1995), the sensemaking process starts with the interpretation of the new phenomenon or situation. The interpretation is done by determining the content of the phenomenon or situation faced, through a subjective, meaning making process. The sensemaking process usually takes effect when individuals are not able to go through their normal routines and need to create new meaning to cope with the reality. In organisations, this situation applies in face of a new situation or sudden event that Weick (1995) termed as an 'organisational shock'. This 'shock' in subsequent, can cause the organisation to experience uncertainties and ambiguities due to the change of routine.

It is practical to assume that GLCs are prone to be confronted with uncertainties and ambiguities as the execution of SDE progresses. Regardless of the degree and magnitude, Weick (1995) sensemaking theory recognised uncertainties and ambiguities as strong sensemaking triggers for individuals in the organisation. The move taken by the Sarawak Government to integrate GLCs in the SDE governance further intensifies the need for an organisational CSR sensemaking analysis in GLCs, particularly among those affected by the implementation of SDE. This article takes the important step to develop a conceptual view of the organisational sensemaking process of CSR in GLCs. The graphical depiction on the operationalisation of this study highlights the integration of Carroll's (1991) Four-Part Pyramid and the seven properties of Weick's (1995) Sensemaking Theory as basis to analysing GLCs interpretation and interpreting process of CSR in the confined focus of SDE. This conceptual view is deemed essential and critical particularly in the preliminary stage of this current study.

\section{SARAWAK DIGITAL ECONOMY (SDE): AN OVERVIEW OF THE ROADMAP, GOVERNANCE AND SIGNIFICANCE}

Sarawak's roadmap to its Digital Economy initiative is built upon the State's aims of reducing socioeconomic divide, developing more business and employment opportunities through its key economic sectors and enablers (see Figure 1). According to Sarawak Chief Minister Datuk Patinggi Abang Johari Tun Openg, the shift in Sarawak's trend of economy at this point is critical in order to strengthen the State's development strategies and to further accelerate its economic growth by overcoming the challenges of the global economy (Bong, 2017). Based on this emphasis, the Chief Minister launched the first version of the Digital Economy Strategies 2018 - 2022 which outlines the 47 strategic action plans, intending to spur 
Sarawak's economic growth to 6\%; as well as to turn Sarawak into a high-income status and developed state by year 2030 (State Service Modernisation Unit Chief Minister's Department, 2017).

For Sarawak, embracing the world of digital economy would also mean encouraging creative and innovative thinking particularly among the young local talents (Ogilvy, 2018). The exposure to new knowledge and development of skills in technologies is vital to equip the local workforce for the world of digital economy. To ensure inclusivity of the rural communities in Digital Economy, the State Government has taken aggressive measures to solve the connectivity issues that surfaced in the rural areas of Sarawak. For instance, the provision of basic infrastructure like the ICT towers as part of the State's long-term plan to reduce the development gap between the urban and rural areas of Sarawak (Department of Statistics Malaysia, 2017, p.35).

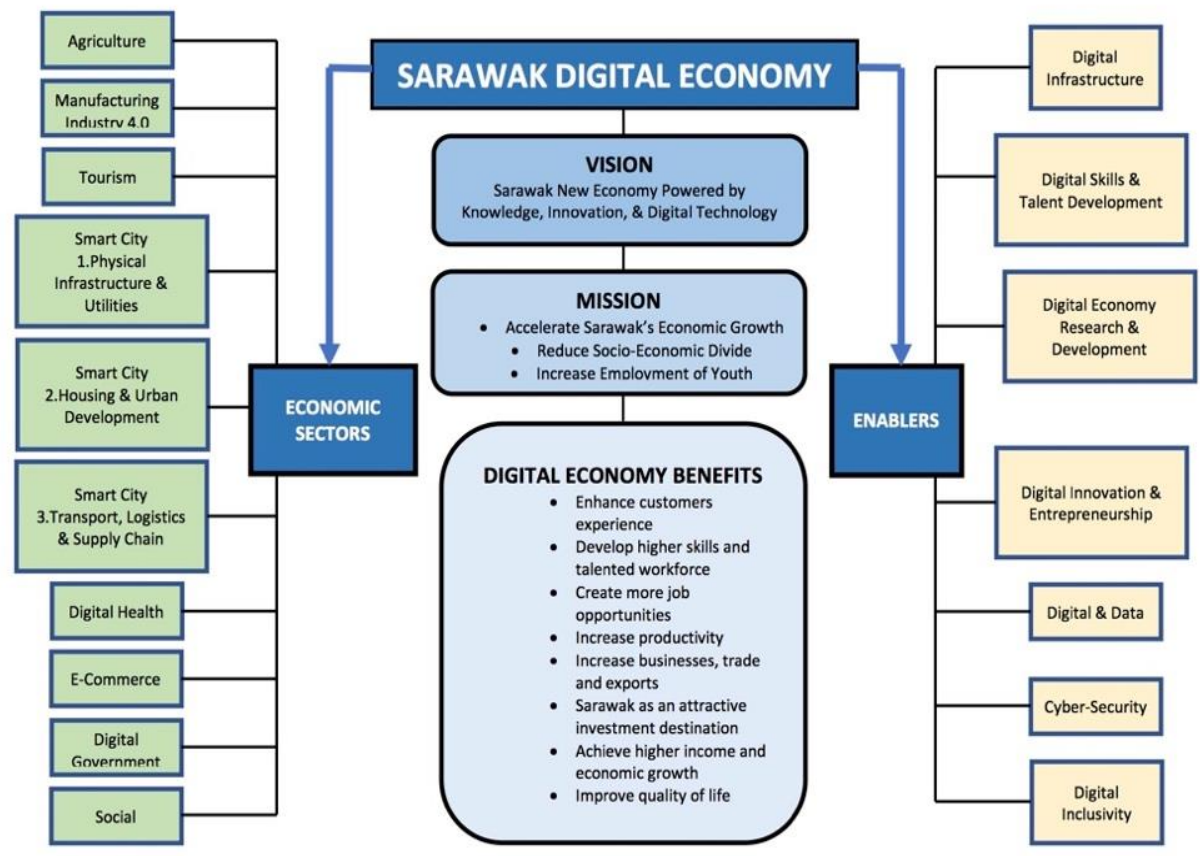

Figure 1: Overview of Sarawak Digital Economy Strategy 2018 - 2022. This chart highlights the vision, mission, and benefits of SDE to the people of Sarawak. This chart also points out the key economic sectors and enablers identified by the Sarawak Government as part of the roadmap to transforming Sarawak into a highincome State by year 2030 (State Service Modernisation Unit Chief Minister's Department, 2017)

The digitalisation of Sarawak's economy is expected to pave ways for the State to achieve high income status and a developed state by year 2030 (Department of Statistics Malaysia, 2017). In moving towards this vision, the State Government has taken multipronged approaches and proactive measures in preparing Sarawak and its people through various digital initiatives. Among the highlighted were the formation of Sarawak Multimedia Authority (SMA) (i.e. responsible to create policies and standards for world-class Sarawak Digital development); the establishment of Sarawak Digital Economy Corporation (SDEC) (i.e. responsible to coordinate various digital economic initiatives like setting up facilities for local youth entrepreneurs to expand and explore business opportunities in the digital economy); the formation of Sarawak Development Bank (DBOS) (i.e responsible to ensure that the revenue generated from financing strategic projects that will prosper Sarawak and the local populace); the launching of Sarawak E-Commerce Transformation Plan 2030 (E-Com Y30) (i.e. 
aims to prepare youth at the Digital Village to graduate as E-Commerce start-ups and entrepreneurs with Digital Knowledge) (Department of Statistics Malaysia, 2017, p.35). Parallel to these efforts, the Sarawak Government has emphasised the need of at least 350,000 supply of tech-savvy workforce by year 2030 (The Borneo Post, 2014; Ogilvy, 2017a). This projected demand of human resources in facilitating the State's economic shift towards digital economy also emphasised the critical role of the Sarawak's Information and Communication sector in ensuring the success of SDE.

The Information and Communication Sector has always been a strong force in the development of Sarawak. Although the Information and Communication has yet to emerge as a significant contributor to the State' Service Sector as compared to the rest of the subsectors, this sector however has consistently projected a steady performance (e.g. growth in value added of sector from a total of RM 10,973 million in 2010 to RM21,195 million in 2015) in fulfilling the goals and expectations of Sarawak's development agenda. (Department of Statistics Malaysia, 2017). The contribution of this sector in promoting digitalisation of economy through the use of ICT were obvious in Sarawak's business environment. The encouraging feedback from local establishments and SMEs on the usage of ICT for business can be detected not only in the increasing usage of computers, internet and websites, but also in form of their involvement in the e-commerce transactions (Department of Statistics Malaysia, 2017). While in the Civil Service, the use of ICT has evidently contributed to the efficiency and productivity of the workforce (Palan \& Putit, 2010).

The Sarawak Government's persistent emphasis in optimising the use of ICT for Sarawak's progress was put to highlight with the establishment of GLCs that were specifically assigned to assist the State Government in the implementation and deployment of ICT related projects throughout Sarawak (Palan \& Putit, 2010). The formation of SAINS for instance has played a vital role in developing ICT infrastructure and providing ICT solutions for the government and local populace. Projects like the Development Project - State Monitoring System (DPMS) has played a significant impact on the efficiency in the monitoring process of government projects throughout Sarawak by providing the efficient means of reporting critical and timely matters (e.g. physical progress of development and geospatial related information for analysis) (Sarawak Information Systems Sdn. Bhd., 2018). Despite the success of these initiatives, the development of ICT particularly in the rural areas are still considered inadequate. Hence the consistent priority put into bridging the digital divide between the urban and rural populace.

The development agenda and strategies set by the Sarawak Government have always be consistently centered within the main objective of reducing the gap between the urban and rural communities, in both progress and pace of development (Berma, M., 2003; Palan \& Putit, 2010; Department of Statistics, 2017; State Service Modernisation Unit Chief Minister's Department, 2017). But due to the geographical landscape of Sarawak, the ability and capacity to bridge the connectivity between the urban and rural populace has imposed a great challenge for the State Government, despite its consistent and progressive effort to improve the socioeconomic condition in both areas (Palan \& Putit, 2010; Department of Statistics, 2017; Sarawak Information Systems Sdn. Bhd., 2018). The connectivity issues like the infrastructure and linkages in most remote areas in Sarawak, is still limited to land-based and water-based transportation, even in this current state (Sarawak Government, 2018). 
In response to the aforementioned constraints faced by the rural population, to establish efficient means of connectivity is critical for the development of Sarawak and its people. This brings the attention to strengthening the State's initiatives in reducing the development gap between the urban and rural populace by way of establishing digital connectivity. Persistent measures toward this effort can be seen in the strategic actions outlined in the roadmap to SDE including the specific approaches to achieving digital inclusivity throughout Sarawak. Another firm step taken by the Sarawak Government to ensure the strategies of SDE are efficiently developed, implemented, and monitored was through the incorporation of SMA, SDEC and State's GLCs in the SDE governance (See Figure 2). This move is expected to assist in the State Government's effort to achieving a digitalready community by year 2030 (State Service Modernisation Unit Chief Minister's Department, 2017).

The incorporation of GLCS in the governance of SDE has strongly positioned the important collaborative role that GLCs hold in the implementation of SDE. Moving alongside the assigned authorities-SMA and SDEC indicates firmly the critical function of GLCS in ensuring successful execution of the strategic actions in the SDE's key focus areas (i.e. Digital Infrastructure, Cyber Security, Talent Development, e-Commerce, Research and Development in digital technology, Digital innovation entrepreneurship, Digital government) (State Service Modernisation Unit Chief Minister's Department, 2017; Ogilvy, 2017b; The Borneo Post, 2017).

It is also important to note that the function of GLCs has taken effect even since the preliminary execution of SDE through the launching of the Sarawak Pay initiative (Ling, 2017). The assigned responsibility to SAINS in developing the operating system for Sarawak Pay exemplifies the close involvement of GLCs in the entire implementation process of SDE. The Sarawak Pay highlights SDE's strategic action on 'Digital Inclusivity' through provision of digital payment (Markus, 2018).

In view of GLCs direct link and close involvement in SDE, it is imperative to also recognise the determining factor of government ownership. Being in a business where the government has major ownership, GLCs in Sarawak are expected to lead others through good practices like CSR (Bidin, 2008; Esa et al., 2012). This research therefore considers GLCs commitment to fulfilling SDE objectives are driven by the ownership aspect of GLC, which in turn reinforces the crucial role of GLCs in SDE. The understanding of GLCs position and function in the context it operates (i.e. SDE) is key to establishing the scope and focus of this current CSR analysis. The practical implication of SDE on GLCs brings this research attention to analysing GLCs' organisational process to developing CSR initiatives that are adaptive and context-related to the confined focus of the new SDE environment. 


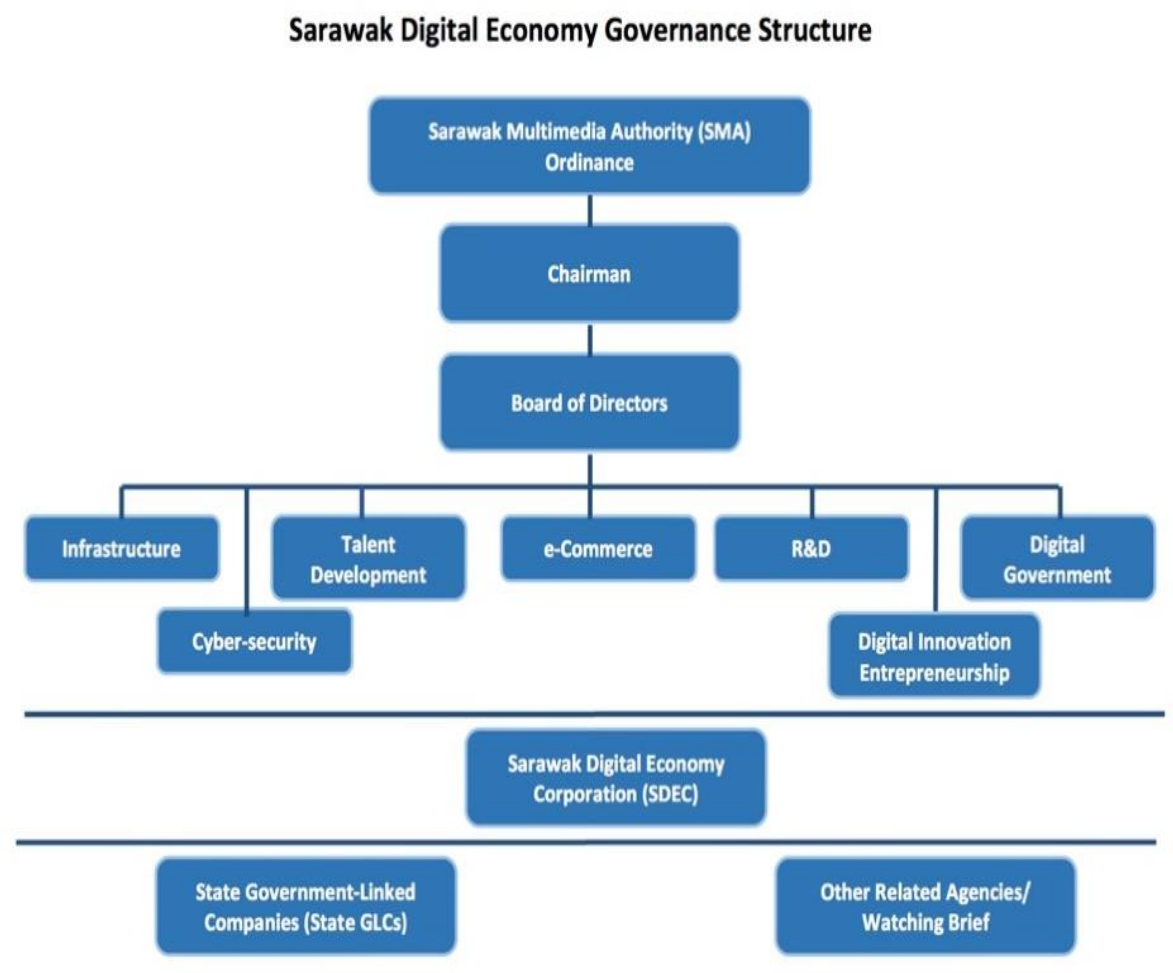

Figure 2: Sarawak Digital Economy Governance Structure. This chart highlights the position and function of State GLCs in the institutional structure and implementation of Sarawak Digital Economy (State Service Modernisation Unit Chief Minister's Department, 2017, pg.10).

\section{ESTABLISHING THE IMPORTANCE OF AN ADAPTIVE AND CONTEXT-RELATED CSR APPROACH AND USAGE OF CARROLL'S FOUR-PART CSR PYRAMID}

The established link between the vital function of GLCs in SDE and the increasing importance of CSR in the socioeconomic growth of Sarawak certainly raises the critical need for a more adaptive and context-related approach to CSR development. Tilt (2016) research on the importance of context in CSR finds that the economic development of a state or country is significant to determining the development of CSR practices among local organisations. Tilt's (2016) findings emphasised on the need for CSR development to take into value the contextual considerations such as specific societal concerns and the state-driven economic plans. Thus, further reaffirms the practical implication of SDE on GLCs is not only extended to its core business, but also in its organisation-specific initiatives such as CSR. With regards to the significant role of GLCs in the SDE governance, it is reasonable for this research to suggest that it is necessary for GLCs to incorporate SDE goals and strategic actions in its CSR objectives and orientations. Hence, the need to develop an adaptive and context-related CSR approach that can accommodate and comply to the specific considerations determined by the SDE environment.

An adaptive and context-related approach has grown to be vital and more prominent in the current CSR practices (Visser, 2006, Porter \& Kramer, 2006; Godfrey \& Hatch, 2007; Jamali, 2007; Basu \& Palazzo; 2008, Scherer \& Palazzo, 2011; Jamali \& Karam, 2018). This approach emphasised the organisation's values and orientation in the creating and collectivizing process of its CSR strategies among the assigned individuals in the organisation (Cramer, 2005). This is by putting more priority to the organisational-specific perspective and meaning of CSR instead of the generic methods and standardised schemes (Cramer \& Loeber, 
2004). This specific meaning making process of CSR that is what makes every CSR strategy of an organisation to be distinctly different from another. Notwithstanding, the different CSR scenarios and contextual factors that one organisation need to encounter and adapt in order to adhere to the expectations entrenched of the environment it operates. This is evident among several SMEs in Malaysia that implemented CSR mainly for moral or ethical reasoning (Chelliah, Jaganathan, \& Chelliah, 2017). However, this motivation differs based on the and (i.e. urban, suburban, state) and even the region where the business takes place. For instance, CSR analysis in developing countries such as Nigeria showcased a contrary outlook on the government's influence on CSR practices among private and multi-national companies (Abdulsalam \& Akinboboye, 2013).

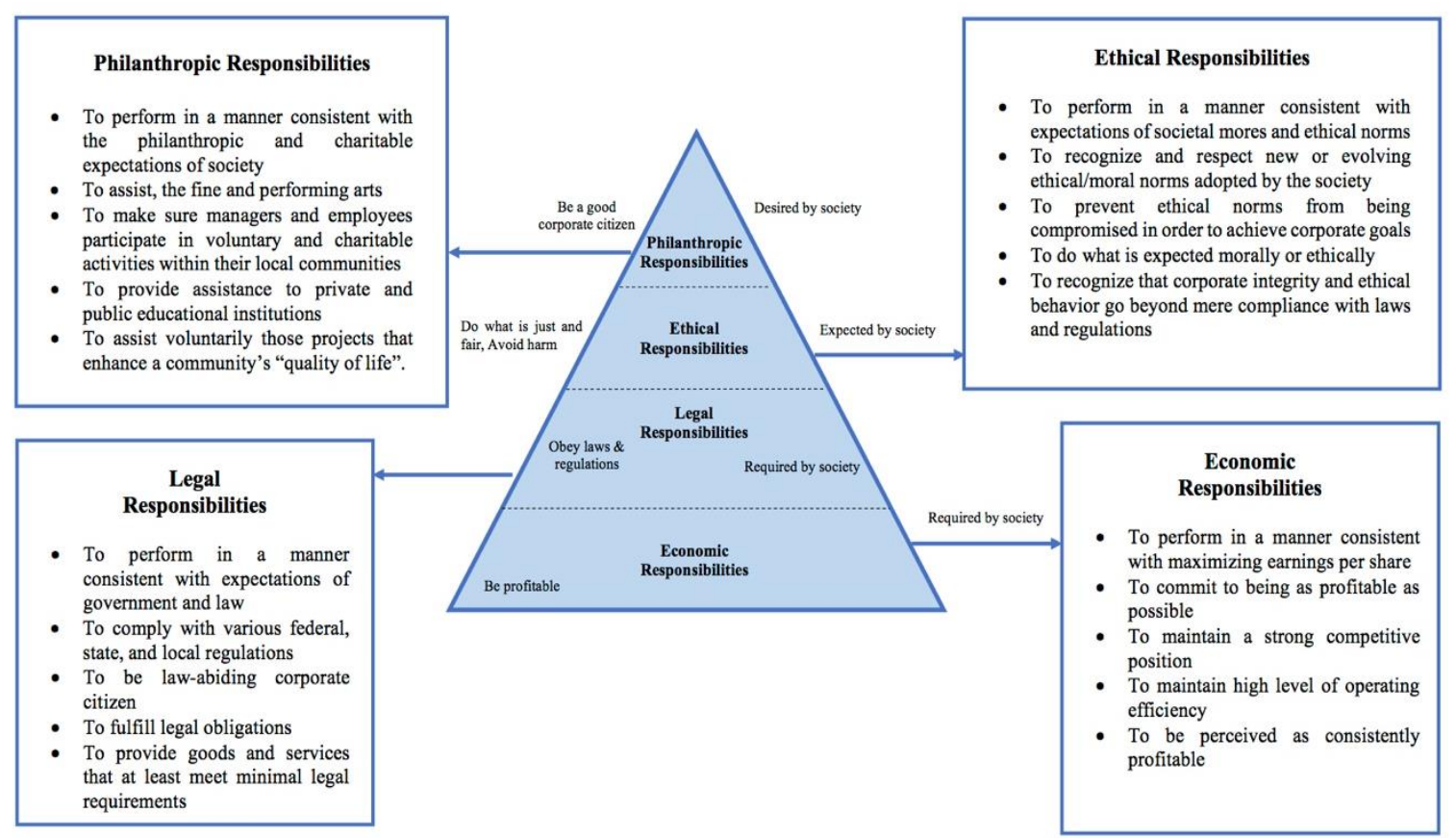

Figure 3: The Pyramid of Corporate Social Responsibility (Carroll, 1991, 2016)

This research takes the pioneering step in developing a conceptual view for the conduct of the intended analysis; that is the CSR development in GLCs in the context of SDE. Following this objective, it is important to firstly establish as to how CSR is conceptualised from the standpoint of this research.

Carroll's Four-Part CSR Pyramid (1991) (see Figure 3) was established upon the understanding that business organisations were set up to supply goods and services to members of society, solely for the purpose of profit. The financial motive was regarded as the main incentive for entrepreneurship; thus, making business organisations as the basic economic entity in a society. Based on this view, 'the economic responsibility was placed as the base of the pyramid because it is a foundational requirement in business; just as the footings of a building must be strong to support society's other expectations of enterprises' (Carroll, 2016, p.4). Similar to the 'economic' components, the other following three parts; namely 'legal', 'ethical', and 'discretionary' constructing the pyramid were derived from Carroll's initial work in 1979. In 1991, the four-part definitional construct of CSR was developed in a pyramid form, with the intention to provide a more illustrative description of each components and as to how it interlinks with each other. 
Carroll's earlier research (Aupperle, Carroll, \& Hatfield, 1985) empirically proven the relevance of these four components in CSR implementation and its correlation. Interestingly, the findings also indicated that the four components can also stand individually as independent concepts; thus, makes it unnecessary for the components to be explained and be put together in a consecutive order (Carroll, 1991). Consistent with this, Carroll in his recent review of his CSR pyramid emphasised on the need to interpret his framework as an integrated and unified whole (Carroll \& Buchholtz, 2015; Carroll, 2016). In other words, the four components constituting the pyramid could also be interpreted as Total Corporate Social Responsibility (TCSR) (i.e. Economic Responsibilities + Legal Responsibilities + Ethical Responsibilities + Philanthropic Responsibilities). From this TCSR perspective, the components in the pyramid must not be perceived and deliberated as an actual sequence and hierarchal order of the organisation's social responsibilities and priorities. In that sense, organisations are expected to fulfil its economic, legal, ethical, and philanthropic responsibilities, concurrently.

In analysing GLCs' CSR development in the context of SDE, it is important for this research to position Carroll's pyramid as a construct that is built upon the four distinct categories of responsibilities that organisations need to comply and fulfil, either gradually or simultaneously. Based on this point, it is pertinent for this research to regard the framework as a unified whole considering that there is possibility for the categories to interact and/or integrate with each other at some point. Establishing the pyramid from both perspective (i.e. categories are either conceptually independent or unified) is essential in allowing this research to analyse and incorporate new contextual factors and/or categories that may emerge from the analysis conducted on the adaptive and context-related CSR approach applied by the local organisation understudy.

\section{ANALYSING CSR IN THE CONTEXT OF SDE: STRENGTHENING CSR ANALYSIS THROUGH THE SENSEMAKING PERSPECTIVE}

The adaptive and context-related approach presents a new way for CSR development. By taking into value the organisation-specific meaning of CSR and its contextual considerations, this approach focuses on developing CSR from the organisational context instead of generic approaches. Based on this emphasis, translating the general notions of CSR into an organisation-specific idea and practice calls for a need of an organisational meaning making process; or what this research refers to as organisational sensemaking. The sensemaking process has become critically important particularly in understanding how organisational members extract and interpret cues from their environment as basis to creating plausible explanations used to "make sense" of what has occurred; especially in face of ambiguities and/or uncertainties (Weick, 1995; Schouten \& Remme, 2006; Mills et al., 2010; AngusLeppan, Metcalf, \& Benn, 2010; Schultz \& Wehmeier, 2010; Maitlis \& Christianson, 2014; Stieglitz, Bunker, Mirbabaie \& Ehnis, 2018).

Ambiguity and uncertainty as they occur and noticed can interrupt individual's ongoing flow and disrupt their understanding. Weick (1995) views ambiguity as the ongoing stream of cues that support several different interpretations at the same time (e.g. crisis assessment); while uncertainty is referred to as imprecision in estimates of future consequences that are conditional on present activities (e.g. risk assessment) (Weick, 1993). Thus, the notion of sensemaking that is centred on equivocality offers primacy to the search and inquiry for meaning as a way to deal with uncertainty and ambiguity. In understanding 
ambiguity and uncertainty in the course of organisational sensemaking, it is important to note that the type and magnitude of "shocks" experienced by organisations can differ from one another. Therefore, the purpose and amount of information that are needed by sensemakers are central to establishing the difference between ambiguity and uncertainty, as well as the kinds of occasions for sensemaking required.

According to Weick (1995), ambiguity and uncertainty are common sensemaking occasions faced by organisations. 'Ambiguity' defined in this research follows the description by Weick (1995, p.92) and the representative definitions (Levine, 1985; Martin, 1992; March, 1994 , as cited in Weick, 1995) he used in capturing the nature of ambiguity in organisational sensemaking; that is ambiguity involves lack of clarity. Extending Burns and Stalker (1961), Stinchcombe (1990, as cited in Weick, 1995) on the other hand, deliberated on the idea of 'uncertainty' from an information-processing perspective.

Consistent with Weick (1995), Stinchcombe's (1990) information-processing viewpoint acknowledges that uncertainty changes over the course of a decision; and this decision is determined not only by the availability to information, but also the capability to scan and interpret the information attained. Information is essential for sensemakers to determine what outcomes will follow from their lines of actions. Hence, emphasises the idea that uncertainty is a form of shock elicited by the inability to extrapolate or reason the current actions and to project the circumstances. In consequence, produces an occasion for sensemaking to reduce ignorance.

In order to reduce or remove ignorance (i.e. uncertainty), more information is required. While to reduce or remove confusion (i.e. ambiguity), a different kind of information of which provides sensemakers with multiple cues are needed (Weick, 1995; Choo, 2002). Unlike uncertainty, facing ambiguity necessitates sensemakers to share information with others and gradually make meaning of the information obtained. In this occasion, the multiple meanings created from the same information would likely to produce shock (Weick, 1995; Maitlis \& Christianson, 2014). Thus, the need to access more cues or more varied cues (Choo, 2002). As Weick (1995) points out, a greater quantity of information is less useful than is a different quality of information. Hence, the importance of organising cues and messages to create meaning through discussion and shared interpretation.

Individuals often construct the reasons to the occurrence of their actions as they unfold, which in subsequent makes it difficult for individuals to forecast the consequences of their actions in advance. Based on this perspective, this research values the need for a proactive approach to handling 'triggered events'. Shrivastava (1987, as cited in Weick, 1988, p.308) identified 'triggered events' as 'a specific event that is identifiable in time and place and traceable to specific man-made causes. There are other forms of issues or events that have been found to trigger sensemaking. Some scholars (Hoffman and Ocasio, 2001, and Nigam \& Ocasio, 2010) identified this "triggered event" as an event that catches the organisation's attention.

Understanding on event that catches attention and noticed by organisations (i.e. triggered events) were also developed through studies conducted in a separate stream of work, external to the sensemaking literature. Bouquet \& Birkinshaw (2008) study on management revealed that the presence of foreign multinationals in a local market turned out to be a sufficient trigger to incite headquarters' attention particularly in identifying location-specific advantages. Following Weick (1995), this research regards both forms of 'triggered events' or 'interruptions' as violations of expectations for both individuals and organisations. 
There are two form of interruptions that are identified as triggers to sensemaking -1 ) a new event that is not expected; 2) an expected event that does not occur. Both forms of interruptions can be considered as violations of expectations or 'organisational shock'. From the sensemaking standpoint, a crisis for instance, is based on what the individual or group (i.e. parties of interest) perceived as crisis. As such the perceived magnitude of the 'interruption' could differ from one's interpretation to another depending on how they make sense of the event, the degree of violation that they can make sense from based on what they experienced, and how they make sense of their reaction towards the 'interruption'.

Following the aforementioned view, Brown (2004) and Boudes and Laroche (2009) examined the ways meaning is constructed through the sensemaking processes following the violation of expectations experienced by the individuals in form of interruption of routines and practices. In reference to this example, this study therefore regards organisational shock(s) as any form of event(s) that could disrupt and influence all process that restricts organisations from relying on its the existing organisational routines (Weick, 1995), including its CSR decisions and actions.

In confronting a 'shock', organisations are prone to be exposed to the need of initiating a novel or different action from its present CSR practices. In that sense, 'organisational shocks' turns into sensemaking triggers that interlock behaviors and structures among individuals in the organisation; particularly on making sense of the ideas and situations built upon the 'interruption' (Weick, 1988; 1995). Based on this perspective, it is reasonable to regard expectations and strategic actions of SDE as a form of 'organisational shock' to the GLCs that are directly affected by the implementation of this economic initiative. In the course of GLCs' CSR development, this 'organisational shock' can turn into sensemaking triggers to the organisation's CSR meaning making process. In view of this possibility with consideration of the incorporation of GLCs in SDE governance, this research therefore interprets SDE as an 'organisational shock' that requires immediate interpretation, especially where the current CSR goals and orientation is concerned. 


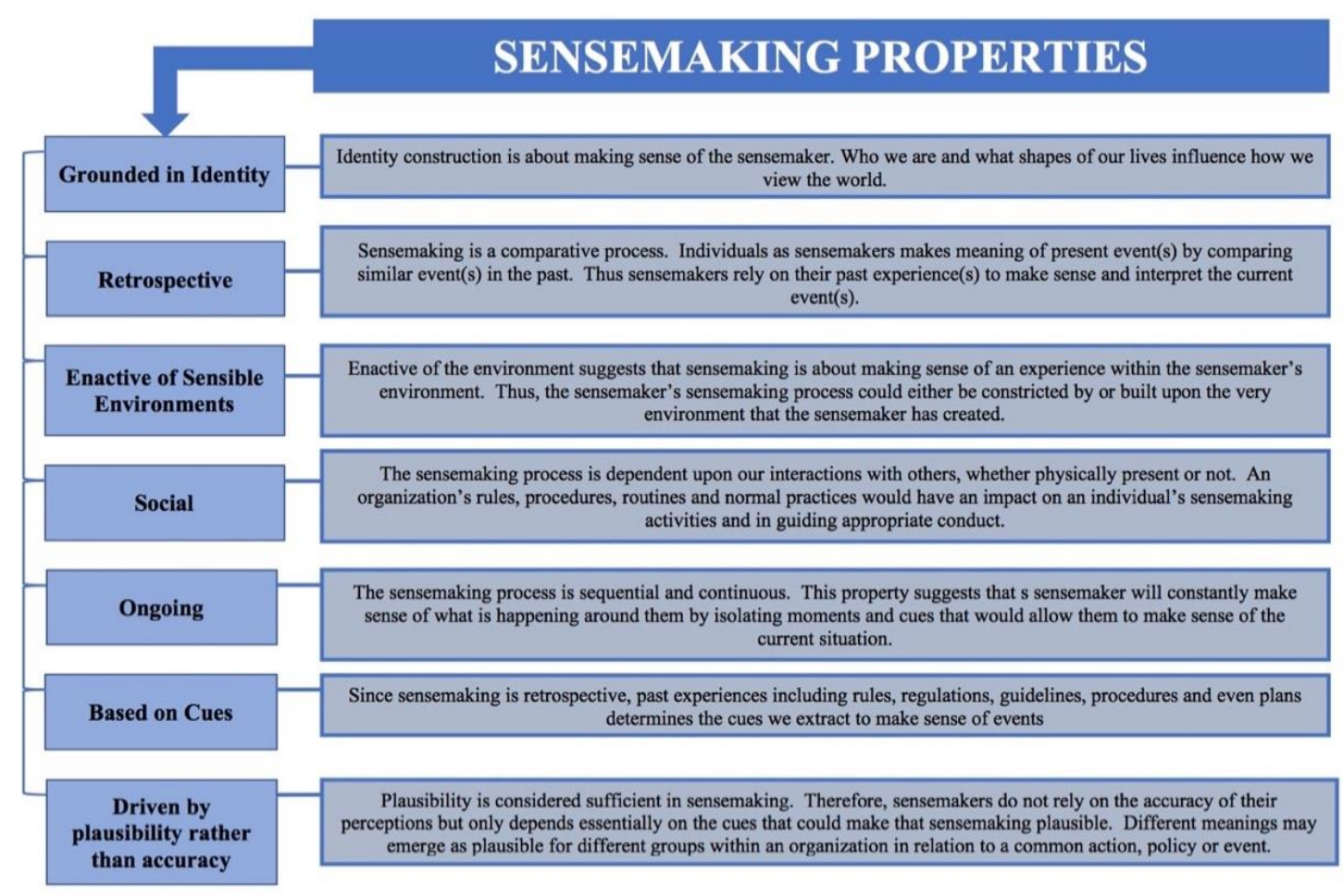

Figure 4: The Properties of Sensemaking (Weick, 1995)

Taking into account the subjectivity of meaning making process in sensemaking, individuals in the organisation are likely to respond differently thus produce varied interpretation of the same situation (Weick et al., 2005). Due to this likelihood, the organisational sensemaking necessitates a collective interpretation of CSR by having the individuals share meanings with each other through the process of social interaction. The varied meaning created by these individuals towards the same event is a result of their sensemaking processes, each in which are influenced by what Weick (1995) identified as the seven interrelated properties of sensemaking in addition to the ongoing nature of sensemaking. 1) grounded in identity construction; 2) retrospective; 3) enactive of sensible environments; 4) social; 5) ongoing; 6) based on cues; 7) driven by plausibility rather than accuracy (see Figure 4).

Following Weick et al. (2005) and Mills et al. (2010), the following seven interrelated properties of sensemaking is described based on the understanding that sensemaking is not a linear process. As such, the conceptual view presented in this article is developed based on the assumption that the prominence of the properties may change in its degree of importance as the sensemaking process unfolds. Taking this into consideration, sensemaking therefore can be treated as a process that requires effort after effort (i.e. further sensemaking) until an individual or group is able to establish a meaningful understanding of the event(s).

The collaborative effort between the Sarawak Government and local organisations like GLCs (see Figure 2) is key to ensuring the successful implementation of SDE (State Service Modernisation Unit, 2017). Due to the critical function and impact of SDE on the local community, it is vital for this research to acknowledge and anticipate SDE's significant influence on local organisations, particularly as a 'trigger' to its organisational sensemaking processes. 
Over the past decades, governments have been part of other stakeholders in undertaking a relevant role as drivers of CSR (Moon, 2004) and adopting public sector roles in strengthening CSR (Fox et al. 2002). For instance, through mechanisms like multistakeholders collaborative partnerships with the corporate and non-governmental organisation (NGO) organisations on projects like CyberCare, the Malaysian Government has shown rigorous effort in reinforcing the importance of CSR as a platform to serving the community's needs and interests (Muda, 2018). Although the emphasis of CSR varies across regions, the ministries' intervention on an organisation's CSR orientation is sufficient to suggest the influential role of the government (Albareda et al., 2008). On this note, it is imperative for this research to acknowledge the prominent role that governments play in the positioning of an organisation's CSR initiative and in determining the extent of its significance to the economic, social and environmental well-being of the surrounding system and community. Based on this evidence, it is practical for this research to suggest for similar nature of involvement and connection between the State Government and the advancement of CSR practices to also takes effect in Sarawak, particularly among the GLCs.

The joint effort between the State Government and local organisations, particularly GLCs (e.g. SAINS) in various scope of CSR development has long been detected since the early 2000s (SAINS). The incorporation of GLCs in SDE governance further strengthens the likelihood of GLCs commitment to incorporate SDE goals and strategic actions not only in its core business, but also in its organisation-specific initiatives like CSR. This research considers that the changes required of GLCs in its CSR routines can to a great extent expose the organisations to ambiguities and/or uncertainties that are likely to surface from the newly established SDE environment. In this respect, it is reasonable and practical for this research to interpret that the changes imposed on GLCs' current CSR routines, as well as the inevitable ambiguities and/or uncertainties faced due to the novelty of SDE as a strong trigger to the organisational CSR sensemaking process. Hence, the critical need to analyse the sensemaking process in the organisations' attempt to develop CSR in response to the implementation of $\mathrm{SDE}$; as well to construct a conceptual view that can help ground and structure the intended analysis in this current study.

\section{FINDINGS AND CONCLUSION: ESTABLISHING THE CONCEPTUAL VIEW OF THE ORGANISATIONAL CSR SENSEMAKING PROCESS IN THE CONTEXT SDE}

The conceptual view of the Organisational CSR Sensemaking Process in the context of Sarawak Digital Economy (see Figure 5) is developed upon the need to analyse the adaptive and context-related approach to CSR development among the local organisations in Sarawak. In significance to the incorporation of local organisations particularly GLCs in the SDE governance, the adaptive and context-related CSR is believed necessary parallel to the effort of fulfilling and complying to the SDE goals and strategic actions. That is, by incorporating the State's economic focus in the organisation-specific CSR initiatives. Based on this priority, this research takes the pioneering step to construct a conceptual view that puts into perspective the organisational internal search process to CSR development that is in line with the context of Sarawak's current economic environment - SDE. This article is significant in providing an illustrative description as to how the thinking and interpreting work should be performed in the organisation's process to make sense of its CSR development in the SDE context of which the organisation currently operates. 


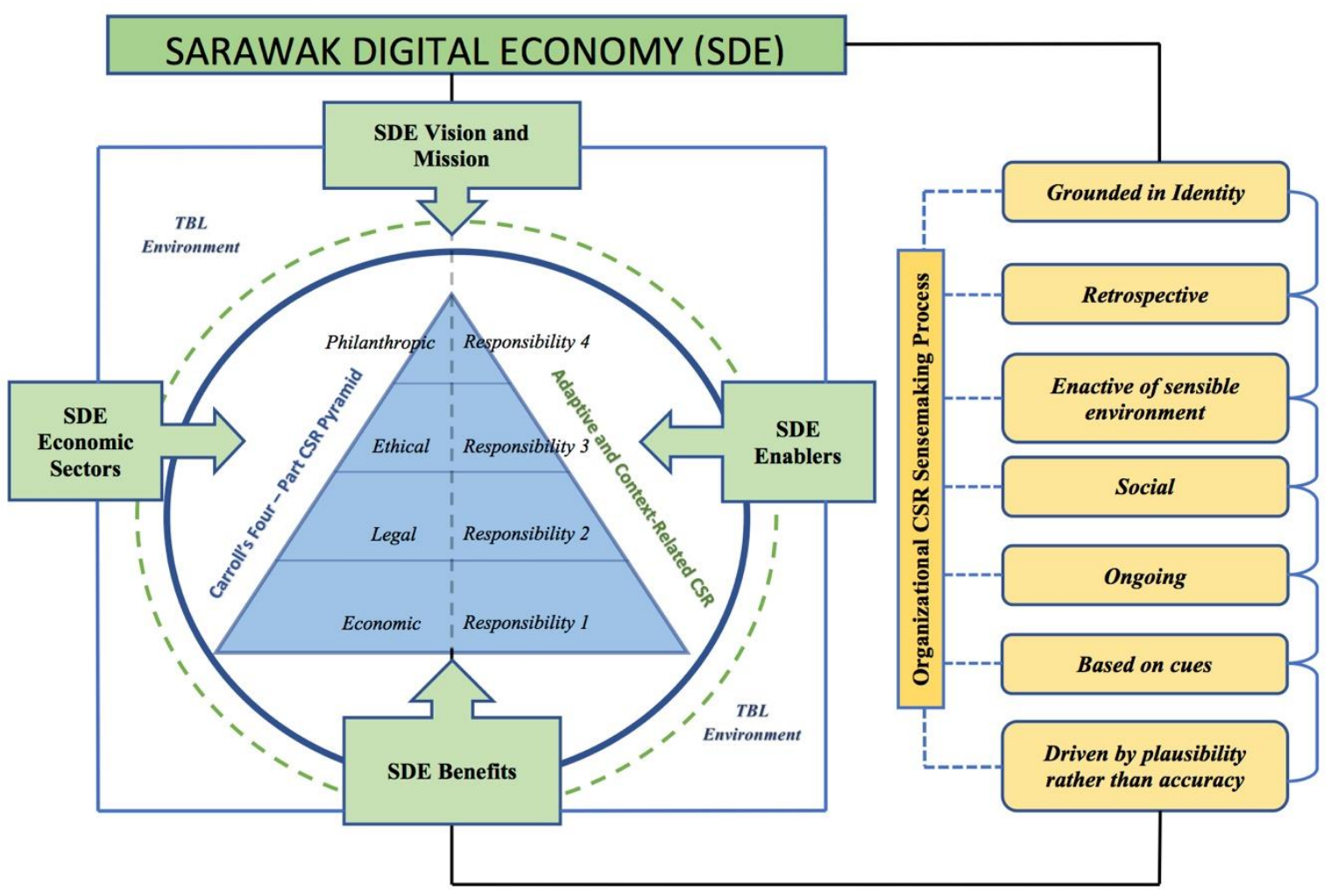

Figure 5: A conceptual view of the Organisational CSR Sensemaking process in the context of Sarawak Digital Economy

For the conduct of this current analysis, the conceptual construct (i.e. Figure 5) is to be used in analysing Organisational CSR Sensemaking in a local organisation that has a direct link and specific function in the implementation of SDE. This research also considers the organisation selected for the purpose of this analysis to be prominently and actively involved in organising CSR activities. This is to allow this research to capture the interactive process of CSR sensemaking among members of the organisation. The intricate process of CSR Sensemaking certainly requires for this present research to view the organisation understudy in a relatively narrow sense; from a standpoint which allows the research to scrutinize the organisation's specific guides and action schemes to its CSR implementation. Hence, a case study approach is required to obtain insights on how the individuals actively create and collectivize meaning of the organisation's CSR, how it is developed, and reconstructed in compliance to the specific goals, strategic actions, and direction of the SDE initiative.

Analysing the internal search process of an organisation's CSR certainly adds value in the current field of CSR and also PR study by focusing on the dimension of meaning making of CSR on the micro-level; that is between members of the organisation. The organisational CSR sensemaking process by the organisational members or the organisation's particularly within the PR department; herein can be described as an act of constructing interpretations of their environment in and through interactions (Schultz \& Wehmeier, 2010). This process of bottom-up sensemaking in the context of this study acknowledges that an organisation's CSR are not fixed scripts and fixed meanings (Weber \& Glynn, 2006); therefore, needs to be constantly interpreted, translated and amended or improved through time. From the PR perspective, this research regards the organisational sensemaking as a proactive initiative 
that is deemed necessary for the organisation in its move towards developing a better understanding, sensitivity and evaluation of the changes, trends or even threats emerging from both its internal and external environment. Scholars regard CSR as a social construct that emerges out of communication (Schultz \& Wehmeier, 2010); and to manage communication flows to support integration and embeddedness of CSR within and external to the organisation is certainly a key step towards active public relations. Herein, by initiating organisational CSR sensemaking, an organisation through its PR department could foster open communication lines for dialogic relationships with members of the organisation and also to stakeholders as part of the environmental scanning effort (Okura, Dozier, Sha, \& Hofsetter, 2008; Pompper, 2015). This process certainly includes understanding and making sense of the newly established government policies like SDE and its potential impact on the organisation and its CSR activities and direction.

\section{ACKNOWLEDGEMENT}

The authors wish to express the utmost appreciation to Kementerian Pendidikan Malaysia (KPM), Universiti Malaysia Sarawak (UNIMAS) and Universiti Sains Malaysia (USM) for supporting the conduct of this study.

\section{BIODATA}

Dayang Aizza Maisha Abang Ahmad is a lecturer at the Faculty of Language and Communication, Universiti Malaysia Sarawak and currently a PhD candidate at the School of Communication, Universiti Sains Malaysia. Her PhD research focuses on organizational sensemaking of Corporate Social Responsibility, particularly in the scope of Sarawak Digital Economy. Email: aadamaisha@unimas.my

Jamilah Hj. Ahmad is a Professor at the School of Communication, Universiti Sains Malaysia. She is currently researching on Environmental Communication, Public Relations, Corporate Social Responsibility (CSR), Communication \& Media Studies, e-Learning and New Media Technology. Email: jahmad@usm.my

Suriati Saad is a lecturer in School of Communication, Universiti Sains Malaysia. Her research includes Corporate Social Responsibility (CSR), Marketing Communication, Social Media and Media Studies. Email: suriatisaad@usm.my 


\section{REFERENCES}

Abdulsalam, B. K., \& Akinboboye, S. (2013). Corporate social responsibility effect on consumer patronagemanagement perspective: Case study of a telecommunication company in Nigeria. Jurnal Komunikasi: Malaysian Journal of Communication, 29(1).

Albareda, L., Lozano, J. M., Tencati, A., Midttun, A., \& Perrini, F. (2008). The changing role of governments in corporate social responsibility: Drivers and responses. Business ethics: A European review, 17(4), 347-363.

Angus-Leppan, T., Metcalf, L., \& Benn, S. (2010). Leadership styles and CSR practice: An examination of sensemaking, institutional drivers and CSR leadership. Journal of Business Ethics, 93(2), 189-213.

Aupperle, K. E., Carroll, A. B., \& Hatfield, J. D. (1985). An empirical examination of the relationship between corporate social responsibility and profitability. Academy of management Journal, 28(2), 446-463.

Basu, K., \& Palazzo, G. (2008). Corporate social responsibility: A process model of sensemaking. Academy of management review, 33(1), 122-136.

Berma, M. (2003). Towards the national vision policy: Review of the new economic policy and new development policy among the Bumiputera communities in Sarawak. The Bumiputera Policy: Dynamics and Dilemma.

Bidin, A. (2008). Corporate social responsibilty: Trends and developments in Malaysia. Jurnal Undang-undang \& Masyarakat (Journal of Law \& Society), 12, 175-189.

Bong, K. (2017, December 14). Advancing into digital world. The Borneo Post Online. Retrieved from http://www.theborneopost.com

Bouquet, C., \& Birkinshaw, J. (2008). Weight versus voice: How foreign subsidiaries gain attention from corporate headquarters. Academy of Management journal, 51(3), 577601.

Calabrese, A., Costa, R., Menichini, T., Rosati, F., \& Sanfelice, G. (2013). Turning corporate social responsibility-driven opportunities in competitive advantages: A twodimensional model. Knowledge and Process Management, 20(1), 50-58.

Carroll, A. B. (1979). A three-dimensional conceptual model of corporate performance. Academy of management review, 4(4), 497-505.

Carroll, A. B. (1991). The pyramid of corporate social responsibility: Toward the moral management of organizational stakeholders. Business horizons, 34(4), 39-48.

Carroll, A. B. (2016). Carroll's pyramid of CSR: Taking another look. International journal of corporate social responsibility, 1(1), 3.

Carroll, A. B., \& Buchholtz, A. K. (2015). Corporate citizenship: Social responsibility, responsiveness, and performance. Classics of Organization Theory, 439.

Chelliah, T. D., Jaganathan, M., \& Chelliah, M. K. (2017). Adoption of corporate social responsibility: Empirical evidence from Malaysian SMEs. Jurnal Komunikasi: Malaysian Journal of Communication, 33(4).

Choo, C. W. (2002). Sensemaking, knowledge creation, and decision making. The Strategic Management of Intellectual Capital and Organizational Knowledge, 79-88.

Cramer, J. (2005). Company learning about corporate social responsibility. Business Strategy and the Environment, 14(4), 255-266.

Cramer, J., \& Loeber, A. (2004). Governance through learning: Making corporate social responsibility in Dutch industry effective from a sustainable development perspective. Journal of Environmental Policy \& Planning, 6(3-4), 271-287. 
Davendran, V. (2013, November 22). Taib: Sains to boost Sarawak state's plan to encourage technical education. The Star Online. Retrieved from https://www.thestar.com.my

Department of Statistics Malaysia. (2017). Economic census 2016: MyState statistics Sarawak. Putrajaya, Malaysia: Author.

Department of Statistics Malaysia. (2018). Sarawak @ a Glance. Retrieved from https://www.dosm.gov.my/v1/index.php?r=column/cone\&menu_id=clJnWTITbWFH dmUwbmtSTE1EQStFZz09

Elkington, J. (2013). Enter the triple bottom line. The triple bottom line (pp. 23-38). London: Routledge.

Esa, E., \& Anum Mohd Ghazali, N. (2012). Corporate social responsibility and corporate governance in Malaysian government-linked companies. Corporate Governance: The International Journal of Business in Society, 12(3), 292-305.

Fox, T., Ward, H., \& Howard, B. (2002). Public sector roles in strengthening corporate social responsibility: A baseline study. Washington, DC: World Bank.

Frankental, P. (2001). Corporate social responsibility-a PR invention?. Corporate Communications: An International Journal, 6(1), 18-23.

Godfrey, P. C., \& Hatch, N. W. (2007). Researching corporate social responsibility: An agenda for the 21st century. Journal of Business Ethics, 70(1), 87-98.

Hamid, F. Z. A., Atan, R., \& Saleh, M. S. M. (2014). A case study of corporate social responsibility by Malaysian government link company. Procedia-Social and Behavioral Sciences, 164, 600-605.

Helms Mills, J., Thurlow, A., \& Mills, A. J. (2010). Making sense of sensemaking: The critical sensemaking approach. Qualitative Research in Organizations and Management: An International Journal, 5(2), 182-195.

Hoffman, A. J., \& Ocasio, W. (2001). Not all events are attended equally: Toward a middlerange theory of industry attention to external events. Organization science, 12(4), 414-434.

Igwe, P. A., Icha-Ituma, A., \& Madichie, N. O. (2018). An evaluation of CSR and social value practices among UK commercial and social enterprises. Entrepreneurial Business and Economics Review, 6(1), 1-18.

Jamali, D. (2007). The case for strategic corporate social responsibility in developing countries. Business and Society Review, 112(1), 1-27.

Jamali, D., \& Karam, C. (2018). Corporate social responsibility in developing countries as an emerging field of study. International Journal of Management Reviews, 20(1), 32-61.

Jamali, D., \& Mirshak, R. (2007). Corporate social responsibility (CSR): Theory and practice in a developing country context. Journal of business ethics, 72(3), 243-262.

Ling, S. (2017, November 15). Sarawak govt. launches mobile app for cashless payment. The Star Online.

Maitlis, S., \& Christianson, M. (2014). Sensemaking in organizations: Taking stock and moving forward. The academy of management annals, 8(1), 57-125.

Markus, D. (2018, May 15). Sarawak pay v2.0 launched. The New Sarawak Tribune.

Moon, J. (2004). Government as a driver of corporate social responsibility: The UK in comparative perspective. ICCSR Research Paper Series 20-2004, ICCSR, University of Nottingham, 2004 (pp. 11-27).

Muda, S. (2018). Establishing long-term partnership to achieve effective partnering: Is it necessary?. Jurnal Komunikasi: Malaysian Journal of Communication, 34(2). 
Nigam, A., \& Ocasio, W. (2010). Event attention, environmental sensemaking, and change in institutional logics: An inductive analysis of the effects of public attention to Clinton's health care reform initiative. Organization Science, 21(4), 823-841.

Nulawadin, S. (2012). The relationship between corporate governance and corporate social responsibility in government linked companies in Malaysia. International Journal for Management Science and Terchnology, 2(3), 54-60.

Ogilvy, G. (2017a, November 25). Sarawak expects its digital economy to make up $17.4 \%$ of its GDP by 2025. The Star Online. Retrieved from https://www.thestar.com.my

Ogilvy, G. (2017b, December 14). Driving its digital economy. The Star Online.

Ogilvy, G. (2018, January 31). Taib: Digital economy is the future. The Star Online.

Okura, M., Dozier, D., Sha, B. L., \& Hofsetter, C. R. (2008). Use of scanning research in decision making: An examination of the environmental imperative and power-control perspective. Journal of Public Relations Research, 21(1), 51-70.

Palan, R., \& Putit, S. (2010). People development: A leader's journey in the transformation of Sarawak - Taib Mahmud. Kuala Lumpur: SMR HR Group Sdn Bhd.

Pompper, D. (2015). Corporate social responsibility, sustainability and public relations: Negotioating multiplex complex challenges. London: Routledge.

Porter, M. E., \& Kramer, M. R. (2006). The link between competitive advantage and corporate social responsibility. Harvard Business Review, 84(12), 78-92.

Sarawak Government. (2018). Economic growth. Retrieved from https://www.sarawak.gov.my/web/home/article_view/204/220/

Sarawak Information Systems Sdn. Bhd. (2018). Corporate profile. Retrieved from http://www.sains.com.my/content.php?id=49

Scherer, A. G., \& Palazzo, G. (2011). The new political role of business in a globalized world: A review of a new perspective on CSR and its implications for the firm, governance, and democracy. Journal of Management Studies, 48(4), 899-931.

Schouten, E. M., \& Remme, J. (2006). Making sense of corporate social responsibility in international business: Experiences from Shell. Business Ethics: A European Review, 15(4), 365-379.

Schultz, F., \& Wehmeier, S. (2010). Institutionalization of corporate social responsibility within corporate communications: Combining institutional, sensemaking and communication perspectives. Corporate Communications: An International Journal, 15(1), 9-29.

State Service Modernisation Unit Chief Minister's Department. (2017). Sarawak digital economy strategy 2018 - 2022. Retrieved from http://www.sbc.org.my/sbcnews/downloads/sarawak-government-policy/561-sarawak-digital-economystrategy-2018-2022-an-overview-booklet

Stieglitz, S., Bunker, D., Mirbabaie, M., \& Ehnis, C. (2018). Sense-making in social media during extreme events. Journal of Contingencies and Crisis Management, 26(1), 4-15.

The Borneo Post Online. (2014, November 26). Sarawak aims to be richest state and to have local investors. Retrieved from http://www.theborneopost.com

The Borneo Post Online. (2017, December 5). Digital economy picked as theme for Sarawak Civil Service Day 2017. Retrieved from http://www.theborneopost.com

Tilt, C. A. (2016). Corporate social responsibility research: The importance of context. International journal of corporate social responsibility, 1(1), 2.

Tuah, Y. (2017, January 22). Bridging the urban-rural divide: SAINS goes the extra mile. The Borneo Post Online. Retrieved from http://www.theborneopost.com 
Visser, W. (2006). Revisiting Carroll's CSR pyramid. Corporate Citizenship in Developing Countries, 29-56.

Weber, K., \& Glynn, M. A. (2006). Making sense with institutions: Context, thought and action in Karl Weick's theory. Organization Studies, 27, 1639-1660.

Weick, K. E. (1988). Enacted sensemaking in crisis situations [1]. Journal of Management Studies, 25(4), 305-317.

Weick, K. E. (1993). The collapse of sensemaking in organizations: The Mann Gulch disaster. Administrative Science Quarterly, 628-652.

Weick, K. E. (1995). Sensemaking in Organizations (Vol. 3). Thousand Oaks: Sage.

Weick, K. E., Sutcliffe, K. M., \& Obstfeld, D. (2005). Organizing and the process of sensemaking. Organization Science, 16(4), 409-421. 